\title{
On a taxonomic position of the weasel (Carnivora, Mustela) from the Cheju Island (South Korea)
}

\begin{abstract}
Alexei V. Abramov
ABSTRACT. The weasel from Cheju Island (formerly — Quelpart Island), which is situated in Korean Strait south of the coast of South Korea, was described as a separate species Lutreola quelpartis Thomas, 1908. The type specimens of Lutreola quelpartis were re-examined and compared with the Japanese weasel Mustela itatsi and the Siberian weasel Mustela sibirica from Korea, Japan, Siberia and China. The analysis of cranial and external characters has revealed that L. quelpartis is to be treated as a subspecies of Mustela sibirica.
\end{abstract}

KEY WORDS: Mustela sibirica, Mustela itatsi, Mustelidae, taxonomy, Cheju (Quelpart) Island.

AlexeiV. Abramov [aav@aa2510.spb.edu], Zoological Institute, Russian Academy of Sciences, Universitetskaya nab. 1, Saint Petersburg 199034, Russia.

\section{Таксономический статус колонка (Carnivora, Mustela) острова Чеджу (Южная Корея)}

\begin{abstract}
А.В. Абрамов
РЕЗЮМЕ. Колонок острова Чеджу (прежнее название - Куэльпарт), расположенного в Корейском проливе, был описан как отдельный вид Lutreola quelpartis Thomas, 1908. Были исследованы типовые экземпляры Lutreola quelpartis. Результаты сравнительного анализа краниометрических и экстерьерных признаков итатси Mustela itatsi и колонков Mustela sibirica из популяций Кореи, Японии, Сибири и Китая свидетельствуют о принадлежности quelpartis к Mustela sibirica.
\end{abstract}

КЛЮЧЕВЫЕ СЛОВА: Mustela sibirica, Mustela itatsi, Mustelidae, таксономия, остров Чеджу (Куэльпарт).

\section{Introduction}

Mustela Linnaeus, 1758 is the largest genus of the family Mustelidae and is widespread worldwide. The taxonomy of Mustela has been studied many times (Heptner et al., 1967; Youngman, 1982; Abramov, 1999, 2000a). Nevertheless, some of the controversial taxonomic matters have been solved just recently. One of them is a taxonomic revision of the sibirica-itatsi complex. The Japanese weasel was first described as a distinct species, Mustela itatsi Temminck, 1884, but later it was considered conspecific with the widespread Siberian weasel, or kolonok, Mustela sibirica Pallas, 1773. Many recent checklists mentioned itatsi as a synonym or a subspecies of $M$. sibirica (Ellerman \& Morrison-Scott, 1951; Imaizumi, 1960; Heptner et al., 1967; Corbet, 1978; Yudin, 1984; Corbet \& Hill, 1992; Wosencraft, 1993).

Based on the mitochondrial DNA cytochrome $b$ sequences, Masuda \& Yoshida (1994a, 1994b) and Kurose et al. (2000) studied the phylogenetic relationships among the Eurasian Mustela species and revealed that there is a relatively larger genetic distance between $M$. itatsi and M. sibirica. Morphological evidences (morphotypic characters of the skull, body size, coloration, and the bacular structure) support for the view that $M$. itatsi is an independent species (Abramov 2000a, b).

The Japanese weasel $M$. itatsi is an indigenous species of Japanese main islands (Honshu, Kyushu, and Shikoku) and adjacent islands (Tsushima, Yakushima, Tanegashima and Ohshima) except for Hokkaido (Abe et al., 1997). In 1932, the Japanese weasel was introduced to Sakhalin, where it now occurs in the southern part of the island. The Siberian weasel, M. sibirica, is widespread in Asia from the Ural Mountains in the west to the Far East and Korea in the east, and is also recorded from some Pacific islands (Hokkaido, Tsushima and Taiwan). This species was also introduced to Honshu. A great number of different taxonomic forms of Mustela sibirica have been described (see Ellerman \& Morrison-Scott, 1951). One of the doubtful forms was described from the Quelpart Island (recent name Cheju or Cheju-do Island). Cheju-do is a large island, situated in Korean Strait south of the coast of South Korea (Fig. 1). The weasel of Quelpart Island was described by Oldfield Thomas as a separate species, Lutreola quelpartis (Thomas, 1908). Based on external and cranial characters, Thomas pointed out that this "Quelpart Mink" could be closer to the Japanese weasel (M. itatsi) than to the Siberian one (M. sibirica). 


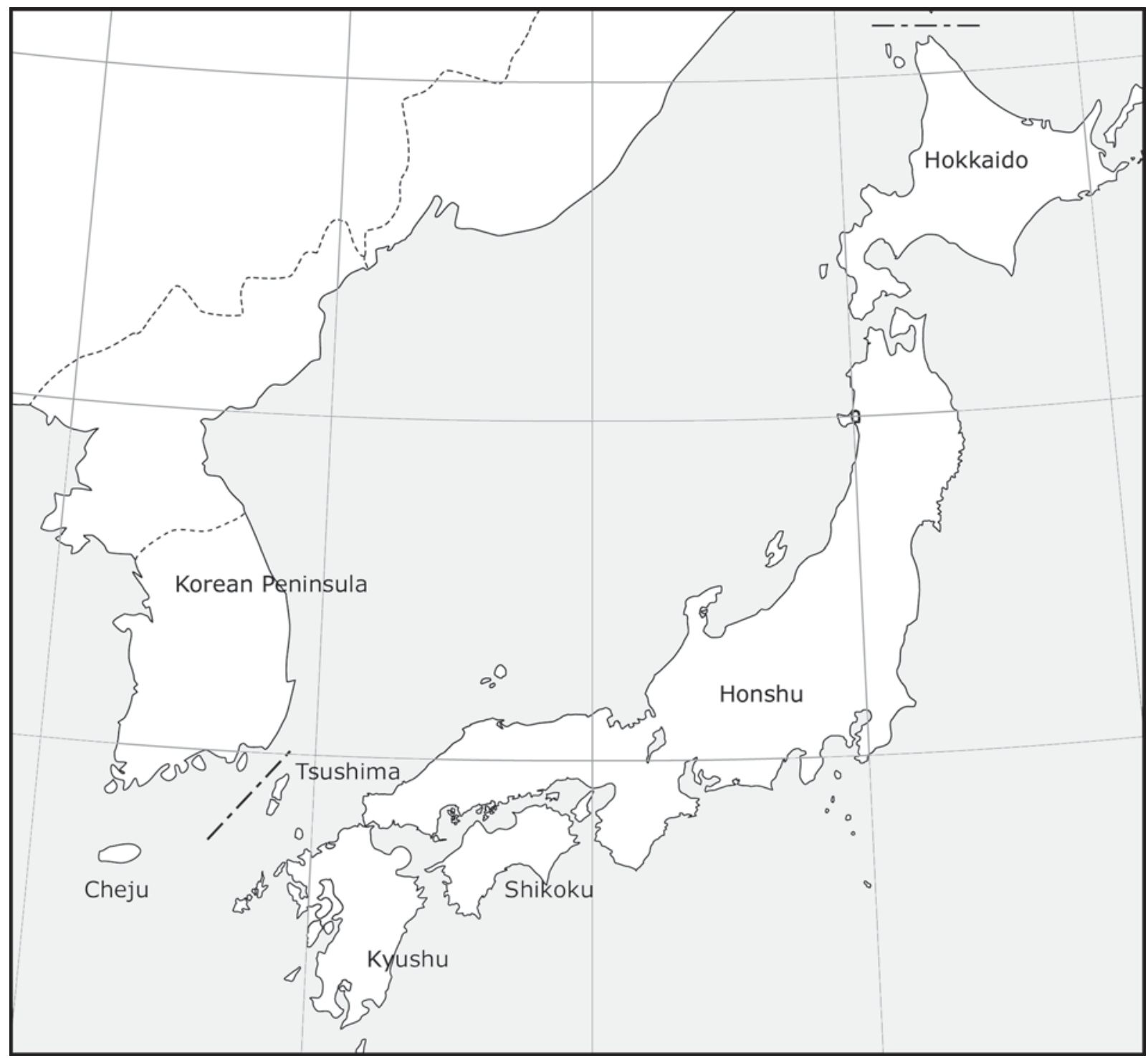

Figure 1. Geographic location of Cheju Island.

The aim of the present study is to clarify the taxonomic status of $L$. quelpartis by comparing the type material with the specimens of $M$. sibirica and $M$. itatsi.

\section{Materials and methods}

The type specimens of Lutreola quelpartis from the Natural History Museum (London, UK) were re-examined: the holotype, NHM 6.12.6.1, adult male, skull, skin; paratypes NHM 6.12.6.2, subadult male, skull, skin; NHM 6.12.6.3, adult female, skull, skin; NHM 6.12.6.4, subadult female, skull, skin. The type specimens were compared with 38 specimens of Mustela itatsi and 165 specimens of Mustela sibirica from Korea, Japan, Siberia and China. Only adult males were used in the statistical analysis in order to minimize variations due to age differences and sexual size dimorphism. The adult specimens were classified on the basis of the most common ageing criteria (obliteration of sutures, tooth wear, bone texture) used in mustelids.

The skulls were classified in following samples: (1) Mustela itatsi from Honshu, Kyushu and introduced populations (Sakhalin, Hokkaido), $\mathrm{n}=38$; (2) Mustela sibirica sibirica from the Urals, Western Siberia, the Altai, Transbaikalia, Yakutia, $\mathrm{n}=97$; (3) Mustela sibirica manchurica from the Russian Far East, North-East China (Manchuria), Korean Peninsula, $\mathrm{n}=51$; Mustela sibirica ssp. from Tsushima Island, $\mathrm{n}=17$. These samples are the representatives of morphologically distinct forms (see Abramov, 2000b).

The collections of the Zoological Institute, Russian Academy of Sciences (Saint Petersburg, Russia), the Institute of Animal Systematics and Ecology, the Siberian Branch of Russian Academy of Sciences (Novosibirsk, Russia), the Zoological Museum of Moscow State University (Moscow, Russia), The Museum, Faculty of 


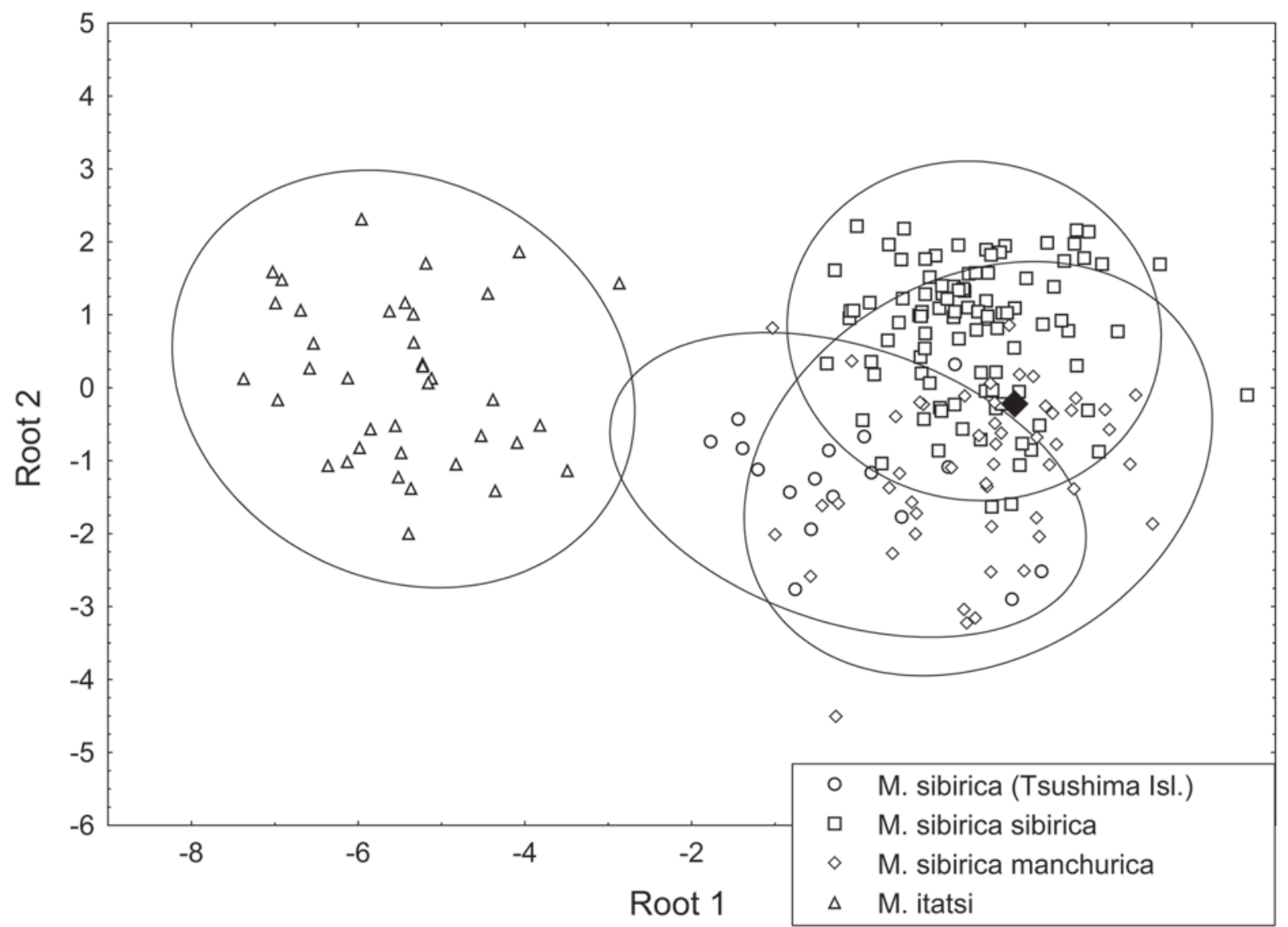

Figure 2. Distribution of the specimens of $M$. itatsi and $M$. sibirica in the space of two first canonical roots. Position of type specimens of quelpartis is shown in back square.

Agriculture, Hokkaido University (Sapporo, Japan), Tomakomai Research Forest, Hokkaido University (Tomakomai, Japan), National Science Museum (Tokyo, Japan), the Kitakyushu Museum and the Institute of Natural History (Kitakyushu, Japan), and Natural History Museum (London, UK) have been examined.

Twenty-two measurements were taken on each skull using sliding caliper with the accuracy of $0.1 \mathrm{~mm}$. The measurements were as follows: 1 - condylobasal length, 2 - neurocranium length, 3 - viscerocranium length, 4 - braincase height, 5 - palatal length, 6 - maxillary tooth-row length, 7 - length of upper carnassial teeth P4, 8 - length of the auditory bulla, 9 - greatest length between oral border of the auditory bulla and aboral border of the occipital condyles, $10-$ zygomatic breadth, 11 - mastoid width of skull, 12 - upper molar M1 breadth, 13 - interorbital width, 14 - breadth at the canine alveoli, 15 - greatest palatal breadth, 16 width of the auditory bulla, 17 - minimal palatal breadth, 18 - total length of the mandible, 19 - length between the angular process and infradentale, 20 - mandibular toothrow length, 21 - length of lower carnassial tooth $\mathrm{m} 1,22$ - vertical height of mandible. The scheme of measurements follows Abramov (2000b).

All statistical calculations were carried out using the STATISTICA 5.5 software.

\section{Results}

The results of the discriminant analysis over 22 cranial characters are shown in Fig. 2. In the space of the first two canonical axes all specimens were divided into two not overlapping clusters that exactly correspond to itatsi and sibirica. The holotype of quelpartis is located in the sibirica cluster.

Except for the size differences, there are morphotypical characters distinguished $M$. sibirica and $M$. itatsi (Abramov, 2000b). The frontal part of the itatsi skull is usually flat, but that in most of the sibirica specimens is convex. The auditory bullae of itatsi are slightly shorter and wider than those of sibirica. Anterior part of auditory bulla of sibirica is noticeably inflated, whereas the bullae of itatsi are more flattened, especially in their anterior parts. Choanal border of itatsi usually has a small medial projection. The tips of processus hamulares of itatsi are usually curved as hooks. Distal parts of the processes hamulares are usually slightly converged behind, so that the choanal notch is oval. Occasionally, there are also other notch's types: triangular or rectangular. The Siberian weasel has the choanal border lacking an acute ledge. The choanal notch of sibirica is triangular (tips of the processus hamulares are noticeably diverging behind) or rectangular (the pro- 
cessus hamulares are almost parallel). Usually, the Siberian weasel has the second upper premolar P2 with two roots, the Japanese weasel with the one-rooted P2. The holotype and paratypes of quelpartis possess all the aforementioned morphotypic characters described for $M$. sibirica.

The weasel from Cheju Island is characterized by smaller size compared to the Siberian weasels from Korean Peninsula and Tsushima Island. In cranial measurements, quelpartis was closer to the nominative form, Mustela sibirica sibirica, from Western Siberia. Based on the result of multi-group discriminant analysis, the type specimen of quelpartis was placed in the M. sibirica sibirica cluster.

The body size of Siberian weasel is larger than that of the Japanese weasel. Body length of adult males of the nominative subspecies of $M$. sibirica varies from 210 to $390 \mathrm{~mm}$ (in average, $360 \mathrm{~mm}$ ), and the tail length varies from 160 to $210 \mathrm{~mm}$ (in average, $175 \mathrm{~mm}$ ). The Far Eastern manchurica is larger; the male body length is $387 \mathrm{~mm}$ in average, and tail length is $183 \mathrm{~mm}$ (Yudin, 1984). According to Abramov (2000b), the body length of adult males of $M$. itatsi varies from 300 to $360 \mathrm{~mm}$ (in average, $331.3 \mathrm{~mm}$ ), tail length from 125 to $157 \mathrm{~mm}$ (in average, $137.9 \mathrm{~mm}$ ). Females' body length varies from 215 to $247 \mathrm{~mm}$ (in average, $230.4 \mathrm{~mm}$ ), tail length from 70 to $98 \mathrm{~mm}$ (in average, $86.8 \mathrm{~mm}$ ). One of the main exterior characters to distinguish sibirica and itatsi is the relative length of tail (Imaizumi, 1960; Abe et al., 1997). That of the Japanese (Korean) population of $M$. sibirica makes more than $50 \%$ of the length of body and head. The Siberian weasel from the Russian Far East also has relatively long tail, reaching 45.6$47.2 \%$ of the body length (Yudin, 1984). In M. itatsi, the relative length of tail varies from 32 to $46 \%$ (the mean for males is 41.6 , for females - $38.5 \%$ ). The body length of adult male of quelpartis is $309 \mathrm{~mm}$, tail length is $153 \mathrm{~mm}$, the body length of adult female is $265 \mathrm{~mm}$, and the tail length is $130 \mathrm{~mm}$. Thus, by external characters, quelpartis is also closer to M. sibirica sibirica than to other forms of the Siberian weasel or to M. itatsi.

\section{Discussion}

Reasoning from the results of this study, the weasel from the Cheju Island is to be placed in Mustela sibiri$c a$. According to results of the previous study (Abramov, 2000b), the Siberian weasel from the northern part of its distribution range is divided into three welldifferentiated forms: Mustela sibirica sibirica, widely distributed from the Urals throughout Siberia eastward to Zeya River basin; M. sibirica manchurica, distributed in the Russian Far East, North-East China (Manchuria) and Korean Peninsula, and a separate form Mustela sibirica ssp., inhabiting Tsushima Island. M. sibirica quelpartis is clearly distinct from the Siberian weasel of Korean Peninsula and Tsushima Island by smaller size.

The Cheju Island is known to have a high level of mammal endemism. Six of the seventeen mammals inhabiting this island present separate subspecies: Crocidura dsinezumi quelpartis, Sorex caecutiens hallamontanus, Rhinolophus ferrumequinum quelpartis, Apodemus agrarius chejuensis, Micromys minutus gertigi, Mustela sibirica quelpartis (Won \& Smith, 1999; Ohdachi et al., 2005).

The Cheju Island was formed by a series of volcanic activities at the end of the Neogene (Park, 1985) and later it was connected to the mainland during the Pleistocene and then separated again ca. 10000 years ago. Koh et al. (2000) analyzed the mitochondrial control region of two subspecies of striped field mice, Apodemus agrarius coreae and Apodemus agrarius chejuensis, to determine the level of genetic divergence between these morphologically distinct taxa. The authors revealed the significant difference between mainland populations of the field mice and that of the Cheju Island. Based on the molecular clock estimate, they suspected that the two subspecies of the field mice might have been isolated at the time of separation of the island from the mainland. The same difference was also found between Korean populations of Sorex caecutiens and the specimens from Cheju Island based on full nucleotide sequences of mitochondrial cytochrome $b$ gene (Ohdachi et al., 2003).

One of most interesting problem in the sibiricaitatsi complex is a migration history and the origin of Mustela itatsi as an endemic species of Japanese Islands. It is possible to hypothesize two ways of the $M$. itatsi origin. First, the Japanese weasel evolved in continental Asia from the ancestor common to M. sibirica. Then it penetrated to Japanese Islands and evolved independently of continental populations. The second idea is that itatsi might have evolved from $M$. sibirica in Japanese Islands.

Based on the considerable morphological differences among eastern populations of $M$. sibirica (Russian Far East, Cheju, Tsushima, Taiwan), it is possible to suspect that ancestral form of $M$. sibirica can evolve rapidly under insular or confined conditions. The Japanese weasel, $M$. itatsi, might reach a species level under the long insular isolation. On the contrary, the low morphological diversity of the Siberian weasels from the Urals to Eastern Siberia (Zeya River) can be the evidence of rapid colonization of this vast territory.

ACKNOWLEDGMENTS. I thank Dr. P. Jenkins, Dr. R. Masuda, Dr. H. Endo, Dr. H. Ichikawa, Dr. M. Baba, Dr. T. Aoi, Dr. E. Zholnerovskaya, and Dr. I. Pavlinov for access to the museum collections under their care. I am grateful to Dr. D. Logunov for improving the English of an earlier draft. I am very grateful to two anonymous reviewers for useful comments on earlier draft of the manuscript. The research was partially supported by the Russian Foundation for the Basic Research grant 06-04-48029.

\section{References}

Abe H., Ishii N., Kaneko Y., Maeda K., Miura S. \& Yoneda M. 1997. A Pictorial Guide to the Mammals of Japan. 
Second edition. Tokyo: Tokai University Press. 195 p. [in Japanese].

Abramov A.V. 1999. [Taxonomy of the Genus Mustela (Carnivora, Mustelidae) of the World]. PhD Thesis. SaintPetersburg: Zoological Institute Russian Academy of Sciences. 200 p. [in Russian].

Abramov A.V. 2000a. A taxonomic review of the genus Mustela (Mammalia, Carnivora) // Zoosystematica Rossica. Vol.8. No.2. P.357-364.

Abramov A.V. 2000b. The taxonomic status of the Japanese weasel, Mustela itatsi (Carnivora, Mustelidae) // Zoologicheskii Zhurnal. T.79. No.1. P.80-88 [in Russian with English summary].

Corbet G.B. 1978. The Mammals of the Palaearctic Region: A Taxonomic Review. London and Ithaca: Cornell University Press. 314 p.

Corbet G.B. \& Hill J.E. 1992. The Mammals of the Indomalayan Region: A Systematic Review. Oxford: Oxford University Press. 488 p.

Ellerman J.R. \& Morrison-Scott T.C.S. 1951. Checklist of Palaearctic and Indian Mammals (1758 to 1946). London: Trustees of British Museum (Natural History). 810 p.

Imaizumi Y. 1960. Coloured Illustrations of the Mammals of Japan. Osaka: Hoikusha. 197 p. [in Japanese].

Heptner V.G., Naumov N.P., Yurgenson P.B., Sludsky A.A., Chirkova A.F. \& Bannikov A.G. 1967. [Mammals of Soviet Union. Vol.2. Part 1. Sea Cows and Carnivora]. Moskva: Vysshaya Shkola. 1004 p. [in Russian].

Kurose N., Abramov A.V. \& Masuda R. 2000. Intrageneric diversity of the cytochrome $b$ gene and phylogeny of Eurasian species of the genus Mustela (Mustelidae, Carnivora) // Zoological Science. Vol.17. No.5. P.673-679.

Masuda R. \& Yoshida M.C. 1994a. A molecular phylogeny of the family Mustelidae (Mammalia, Carnivora), based on comparison of mitochondrial cytochrome $b$ nucleotide sequences // Zoological Science. Vol.11. No.4. P.605-612.

Masuda R. \& Yoshida M.C. 1994b. Nucleotide sequence variation of cytochrome $b$ genes in three species of weasels Mustela itatsi, Mustela sibirica, and Mustela nivalis, detected by improved PCR product-direct sequencing technique // Journal of Mammalogical Society of Japan. Vol.19. No.1. P.33-43.

Ohdachi S.D., Abe H. \& Han S.-H. 2003. Phylogenetical positions of Sorex sp. (Insectivora, Mammalia) from Cheju Island and $S$. caecutiens from the Korean peninsula, inferred from mitochondrial cytochrome $b$ gene sequences // Zoological Science. Vol.20. No.1. P.91-95.

Ohdachi S.D., Abe H., Oh H.S. \& Han S.-H. 2005. Morphological relationships among populations in the Sorex caecutiens/shinto group (Eulipotyphla, Soricidae) in East Asia, with a description of a new subspecies from Cheju Island, Korea // Mammalian Biology. Vol.70. No.5. P.345-358.

Park D.W. 1985. Geology of coasts and mountains in ChejuDo // Cheju-Do study. Vol.2. P.321-322.

Pavlinov I.Ya., Borisenko A.V., Kruskop S.V. \& Yakhontov E.L. 1995. [Mammals of Eurasia. II. Non-Rodentia: Systematic and Geographic Reference Book]. Moskva: Izdatel'stvo Moskovskogo Gosudarstvennogo Universiteta. 336 p. [in Russian].

Thomas O. 1908. The Duke's of Bedford's Zoological exploration in Eastern Asia. VII. List of mammals from the Tsu-shima Islands // Proceedings of Zoological Society of London. Vol.1. P.47-54.

Won C. \& Smith K.G. 1999. History and current status of mammals of the Korean Peninsula // Mammal Review. Vol.29. No.1. P.3-33.

Wozencraft W.C. 1993. Order Carnivora // Wilson D.E. \& Reeder D.M. (eds.). Mammal Species of the World: A Taxonomic and Geographic Reference. Second edition. Washington and London: Smithsonian Institution Press. P.279-348.

Yudin V.G. 1984. Order Carnivora // Krivosheev V.G. (ed.). [Terrestrial Mammals of the Far East of USSR]. Moskva: Nauka. P.216-316 [in Russian]. 